\title{
NUMBER OF PANDEMIC INFLUENZA CASES IN BRAZIL IN 2009 AND 2010
}

\section{ORIGINAL ARTICLE}

TORRES, Carine Correa ${ }^{1}$, FACCO, Lucas², FECURY, Amanda Alves³ ${ }^{3}$ ARAÚJO, Maria Helena Mendonça de ${ }^{4}$, OLIVEIRA, Euzébio de ${ }^{5}$, DENDASCK, Carla Viana ${ }^{6}$, SOUZA, Keulle Oliveira da ${ }^{7}$, DIAS, Claudio Alberto Gellis de Mattos ${ }^{8}$

TORRES, Carine Correa. Et al. Number of cases of pandemic influenza in Brazil in 2009 and 2010. Revista Científica Multidisciplinar Núcleo do Conhecimento. Year 05, Ed. 11, Vol. 25, pp. 81-92. November 2020. ISSN: 2448-0959, Acess Link: https://www.nucleodoconhecimento.com.br/health/pandemic-influenza, DOI: 10.32749/nucleodoconhecimento.com.br/health/pandemic-influenza

\section{SUMMARY}

Pandemic Influenza is an extremely transmissible infectious disease. The main symptoms an individual may develop are: cough, sore throat, runny nose, fever and difficulty breathing. The objective of this work was to show the number of cases of pandemic influenza in Brazil in the years 2009 and 2010. Research carried out in the database of the Department of Informatics of the Unified Health System of Brazil DATASUS (http://datasus.saude.gov.br/). The influenza virus has as characteristic its

\footnotetext{
${ }^{1}$ Mining technician, graduated from the Federal Institute of Amapá (IFAP).

2 Student of the Medical Course of the Federal University of Amapá (UNIFAP).

${ }^{3}$ Biomedical, PhD in Tropical Diseases, Professor and researcher of the Medical Course of the Federal University of Amapá (UNIFAP).

${ }^{4}$ Physician, Professor and researcher of the Medical Course of the Federal University of Amapá (UNIFAP).

${ }^{5}$ Biologist, PhD in Topical Diseases, Professor and researcher of the Physical Education Course of the Federal University of Pará (UFPA).

${ }^{6}$ Theologian, PhD in Psychoanalysis, researcher at the Center for Research and Advanced Studies - CEPA.

${ }^{7}$ Sociologist, Master's student in Anthropic Studies in the Amazon, Member of the Research Group "Laboratory of Education, Environment and Health" (LEMAS/UFPA).

${ }^{8}$ Biologist, PhD in Theory and Behavior Research, Professor and researcher of the Graduate Program in Professional and Technological Education (PROFEPT), Federal Institute of Amapá (IFAP).
}

RC: 68478

Disponível em: https://www.nucleodoconhecimento.com.br/health/pandemic- 
extreme transmissibility, a factor that contributed to the high number of infected. In 2010, a numerical reduction in cases was noted, probably due to the expansion of population knowledge about the prevention and knowledge of the disease and its organic implications. It was observed that, in 2009 and 2010, there were more cases of pandemic influenza among females (mostly in women of childbearing age, whether pregnant or not), in Brazil, and consequently higher number of deaths. When compared to 2009, in 2010 there were more cases in which the patient evolved positively, reaching the outcome of cure.

Keywords: Epidemiology, pandemic influenza, influenza.

\section{INTRODUCTION}

Pandemic Influenza is an extremely transmissible infectious disease that can reach large areas, such as a country or an entire continent, due to the rapid evolution of the virus. Influenza can affect the respiratory system and, if not adequately treated, lead to death (ANDRADE et al., 2012; LENZI et al., 2012).

Its transmission can occur through contact between individuals who have traveled to countries that have reports of influenza cases (and ended up infected), or by contact with infected individuals from the same place of residence. It can also occur through small particles released by a carrier of the virus when coughing or sneezing, leaving such biological material in the environment. These particles can lodge in the airways of a healthy individual, infecting him or her. Upon contact with infected surfaces, when taking your hands to the eyes or mouth, for example, contamination may also occur. (MARQUES et al., 2011; ROSSETTO e LUNA, 2016; SAKAl et al., 2010).

The main symptoms an individual may develop are: cough, sore throat, runny nose, fever and difficulty breathing. In some cases, the individual does not present the described symptoms or presents them in an almost imperceptible way, or develops a more severe condition, and may evolve to death (LENZI et al., 2012).

RC: 68478

Disponível em: https://www.nucleodoconhecimento.com.br/health/pandemic- 
Treatment with antivirals (Oseltamivir or Zanamivir) should be indicated and initiated even if the case is still confirmed (CARNEIRO et al., 2010).

Influenza can be prevented through self-care and vaccination (ROSSETTO and LUNA, 2015). Simple practices such as personal hygiene care, correct and frequent hand washing, avoiding contact with infected individuals (especially indoors), or using a disposable handkerchief when sneezing and coughing can prevent influenza contagion. Health professionals should be excused from work (for a safe period of time) if they show any symptoms or have relatives with the symptoms. Another form of prevention is immunization through annual vaccination campaigns. The vaccine seems to reduce the number of influenza cases. Vaccination is done from the insertion of the inactive virus in the human body, causing the latter to produce antibodies. Antibodies are proteins that act to fight the virus. (CARNEIRO et al., 2010; MELO et al., 2019).

Once ill, it is advisable to avoid contact with other healthy and uninfected individuals, to remain in airy places and at rest. Do not share personal objects such as glasses, towels, soaps, among others. It is also necessary to distribute medicines to the population with identified cases, in order to ensure that influenza does not continue to spread rapidly and contaminate a very large contingent of individuals (GRECO et al., 2009).

In 2009, 88,464 cases of influenza were reported in Brazil, of which 50,482 were confirmed. In 2010, 9,385 cases were reported, of which 973 were confirmed (BRASIL, 2012).

In 2009, in northern Brazil, 2,121 cases of influenza were reported, of which 868 were confirmed. In addition: in the Northeast region, 3,094 cases were counted, with 846 confirmed; in the Southeast region, 31,020 cases were reported, of which 12,104 were confirmed; in the South region, 49,459 cases were reported, with 35,397 confirmed; and in the Midwest region, 2,770 cases of influenza were recorded, of

$\mathrm{RC}: 68478$

Disponível em: https://www.nucleodoconhecimento.com.br/health/pandemic- 
which 1,267 of these cases were confirmed. In the period of 2010, the northern region of the country reported 1,089 , of which 319 were confirmed as influenza. Also: in the Northeast region, 666 were reported, with 152 confirmed cases; in the Southeast region, 4,482 were recorded, with 120 confirmed cases; in the South region 2,573 cases were reported, of which 364 were confirmed; and in the Midwest region, 575 cases of influenza were reported, and 18 cases were confirmed (BRASIL, 2012).

\section{GOAL}

To show the number of cases of pandemic influenza in Brazil in 2009 and 2010.

\section{METHOD}

Research carried out in the database of the Informatics Department of the Brazilian Unified Health System ( DATASUS (http://datasus.saude.gov.br/), to verify the frequency of pandemic influenza cases in Brazil, according to the following steps: A) access, in the main menu, the "Access to Information" bar was accessed; then, it was left to "Health Information (TABNET)" and clicked on "Epidemiological and Morbidity". On the next page we selected "Diseases and Diseases of Notify - From 2007 onwards (SINAN)". The item "Influenza Pandemic" was selected on the page that opened. B) within the tab "Pandemic Influenza - SINAN - Brazil", selected: B1) in the Line field "Years $1^{\circ}$ Symptoms", in the field Column "Not Active" and in the Field Content "Frequency". These and all of the following data were collected in 2009 and 2010. B2) in the "Notification Region" Row field, in the "Not Active" column field, and in the "Frequency" Content field. B3) in the "Final Classification" Row field, in the "Not Active" Column field, and in the "Frequency" Content field. B4) in the "Evolution Case" Row field, in the "Not Active" Column field, and in the "Frequency" Content field. B5) in the "Age Range" field, in the "Not Active" Column field, and in the "Frequency" Content field. B6) in the "Race" Line field, in the "Not Active" Column field, and in the "Frequency" Content field. B7) in the "Sex" Line field, in the "Not

RC: 68478

Disponível em: https://www.nucleodoconhecimento.com.br/health/pandemic- 
Active" column field, and in the "Frequency" Content field. The data was compiled within the Excel application, a component of the Microsoft Corporation Office suite. The bibliographic research was carried out in scientific articles, using computers from the computer laboratory of the Federal Institute of Education, Science and Technology of Amapá, Macapá Campus, located at: Rodovia BR 210 KM 3, s/n Bairro Brasil Novo. CEP: 68.909-398, Macapá, Amapá, Brasil.

\section{RESULTS}

Figure 1 shows the number of cases of pandemic influenza in Brazil between 2009 and 2010. In 2009, data indicate that the number of cases of pandemic influenza in Brazil was about ten times higher than in 2010.

Figure 1 Shows the number of cases of pandemic influenza in Brazil in 2009 and 2010.

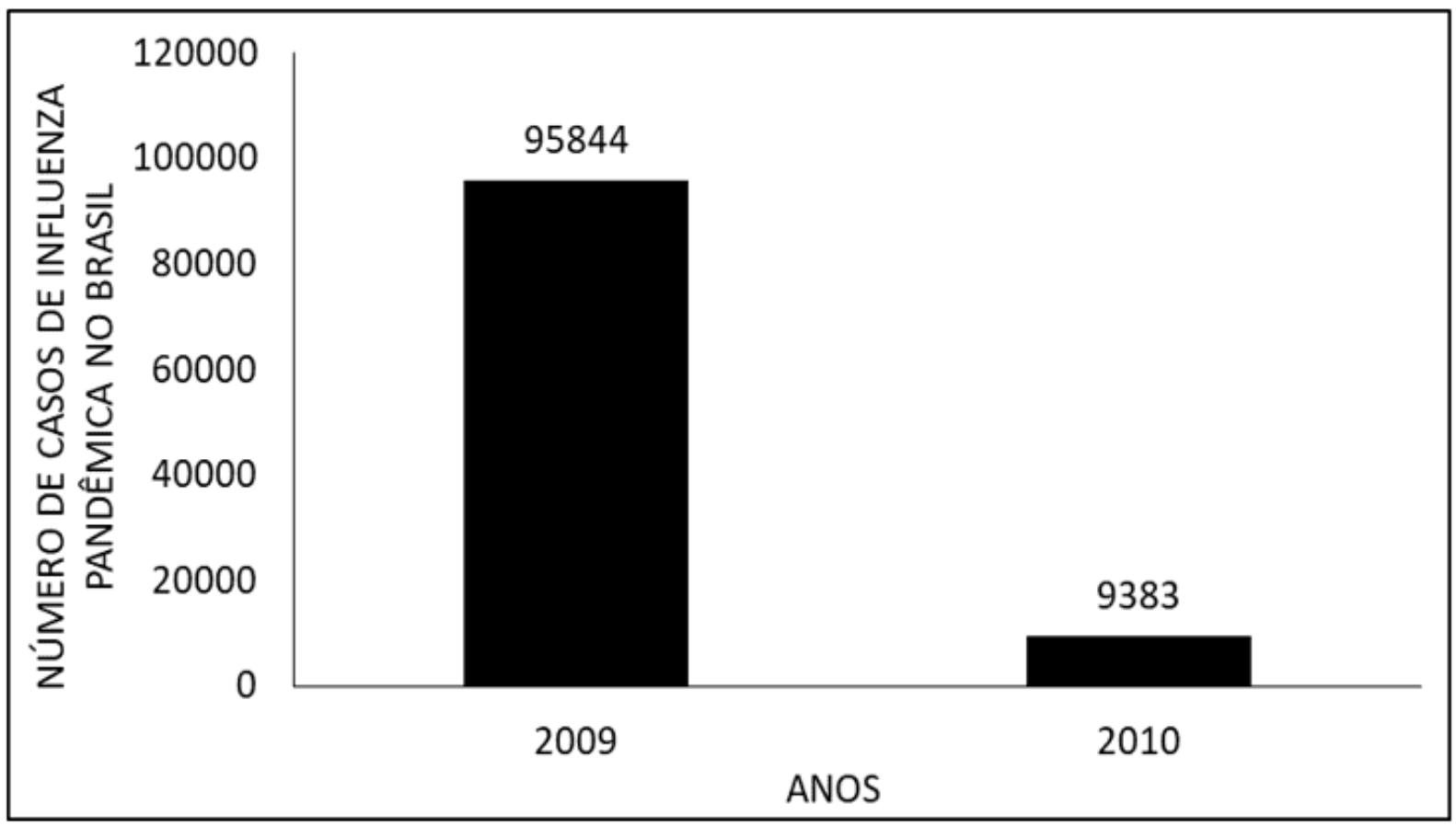

RC: 68478

Disponível em: https://www.nucleodoconhecimento.com.br/health/pandemic- 
Figure 2 shows the number of cases of pandemic influenza in Brazil per quarter in 2009 and 2010. In 2009, the highest number of cases of pandemic influenza were identified in the 2nd, 3rd and 4th trimesters, showing a large increase in the 3rd trimester. In 2010, the highest number of cases of pandemic influenza were presented in the 1st, 2nd and 3rd trimesters, especially in the 2nd trimester, which showed the greatest increase in cases.

Figure 2 Shows the number of cases of pandemic influenza in Brazil, per quarter, in the years 2009 and 2010.

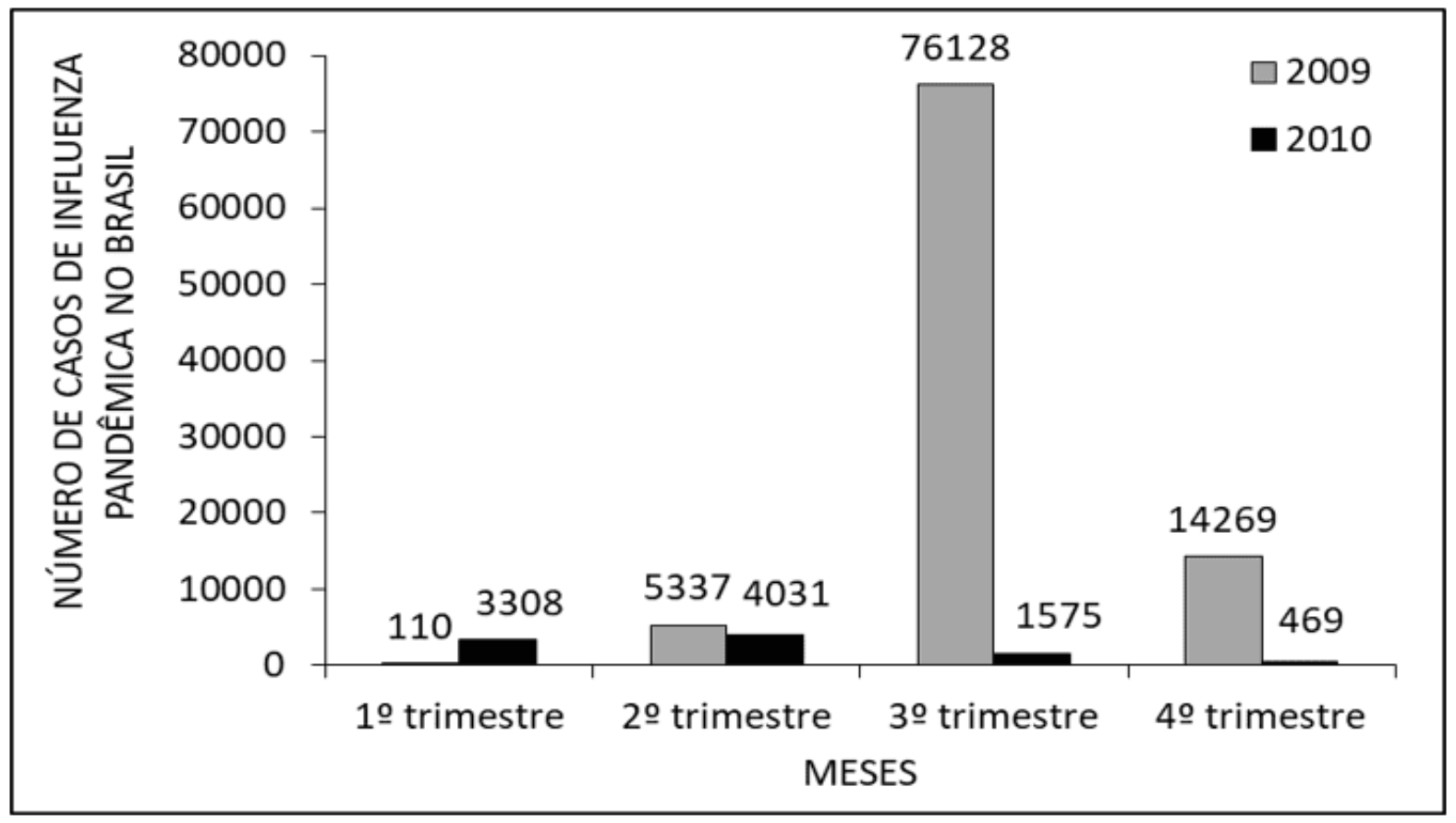

Figure 3 shows that, both in 2009 and 2010, the South and Southeast regions had the highest cases of pandemic influenza in the country, when compared to the other regions. When the years are compared with each other, there is a wide reduction in the number of cases in 2010.

RC: 68478

Disponível em: https://www.nucleodoconhecimento.com.br/health/pandemic- 
Figure 3 Shows the number of cases of pandemic influenza in Brazil, by region, in the years 2009 and 2010.

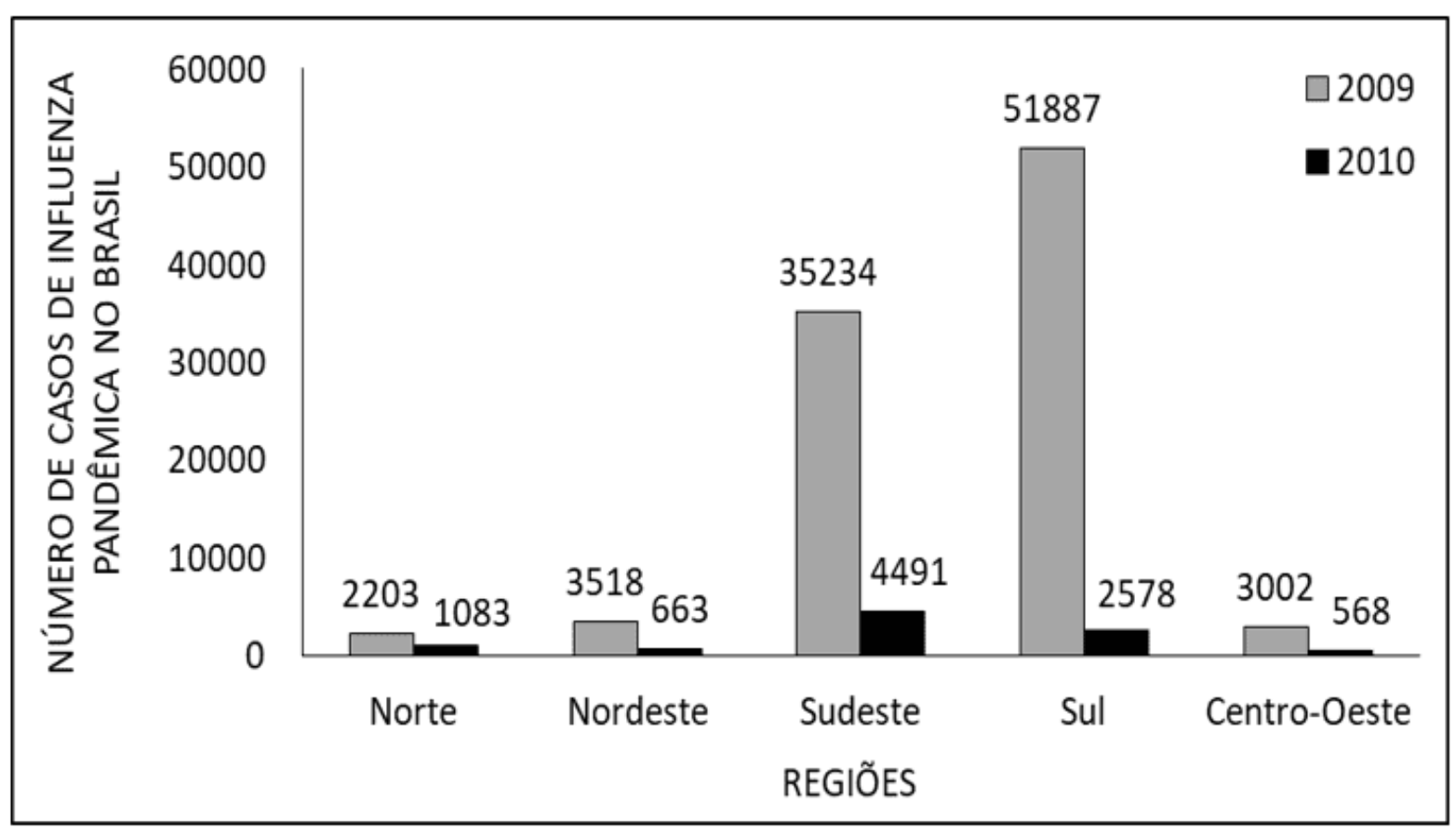

Figure 4 shows that, in 2009, the female population presented a higher number of cases of pandemic influenza than the male population. In 2010, this desiquilíbrio continued, but with a much smaller difference.

RC: 68478

Disponível em: https://www.nucleodoconhecimento.com.br/health/pandemic- 
Figure 4 Shows the number of cases of pandemic influenza in Brazil in 2009 and 2010, by gender.

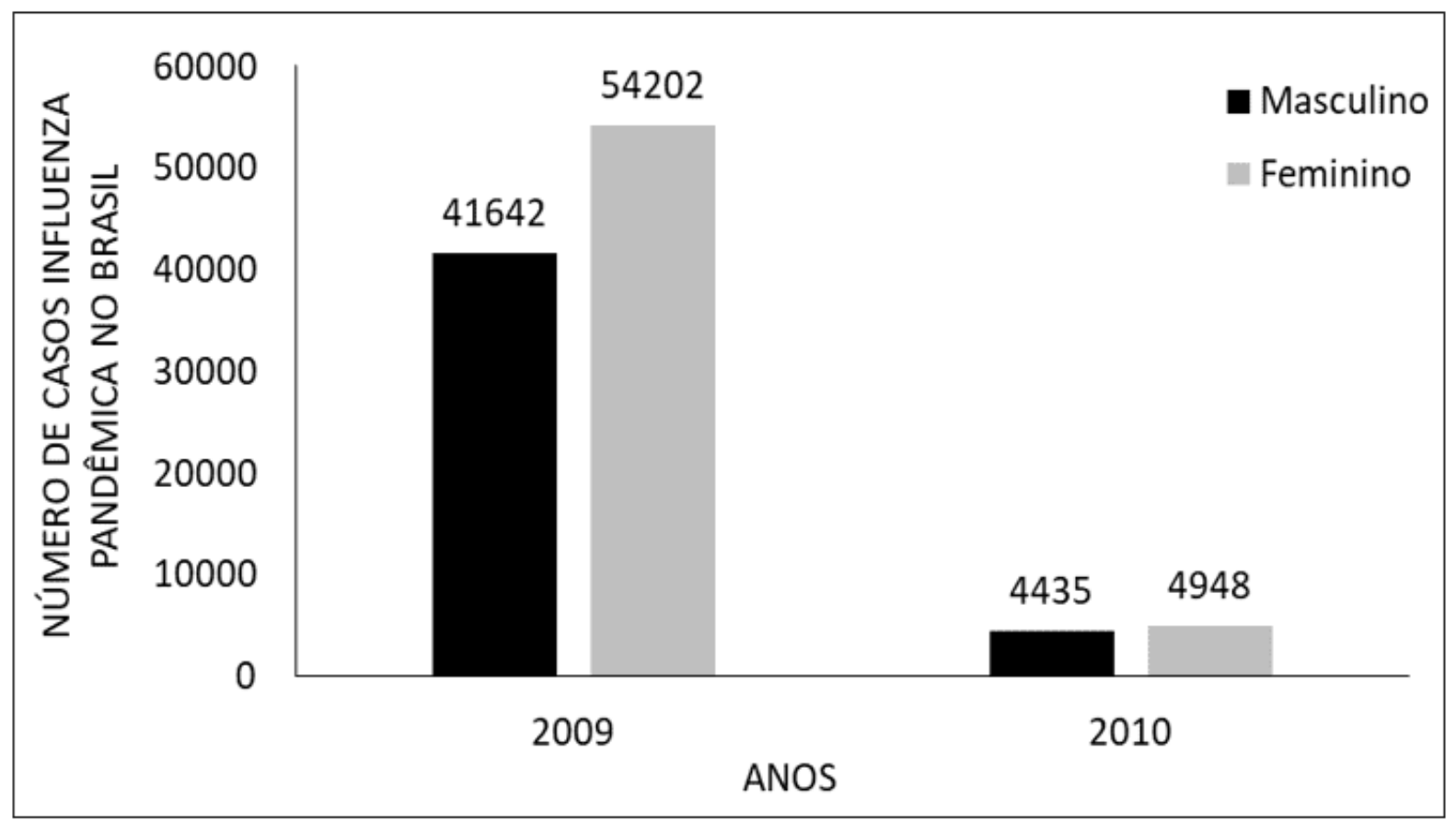

Figure 5 shows that, in 2009, the highest number of cases of pandemic influenza was identified in individuals aged 20 to 29 years. In 2010, the highest number of cases was identified in individuals under the age group of less than two years of age.

RC: 68478

Disponível em: https://www.nucleodoconhecimento.com.br/health/pandemic- 
Figure 5 Shows the number of cases of pandemic influenza in Brazil in 2009 and 2010 by age group.

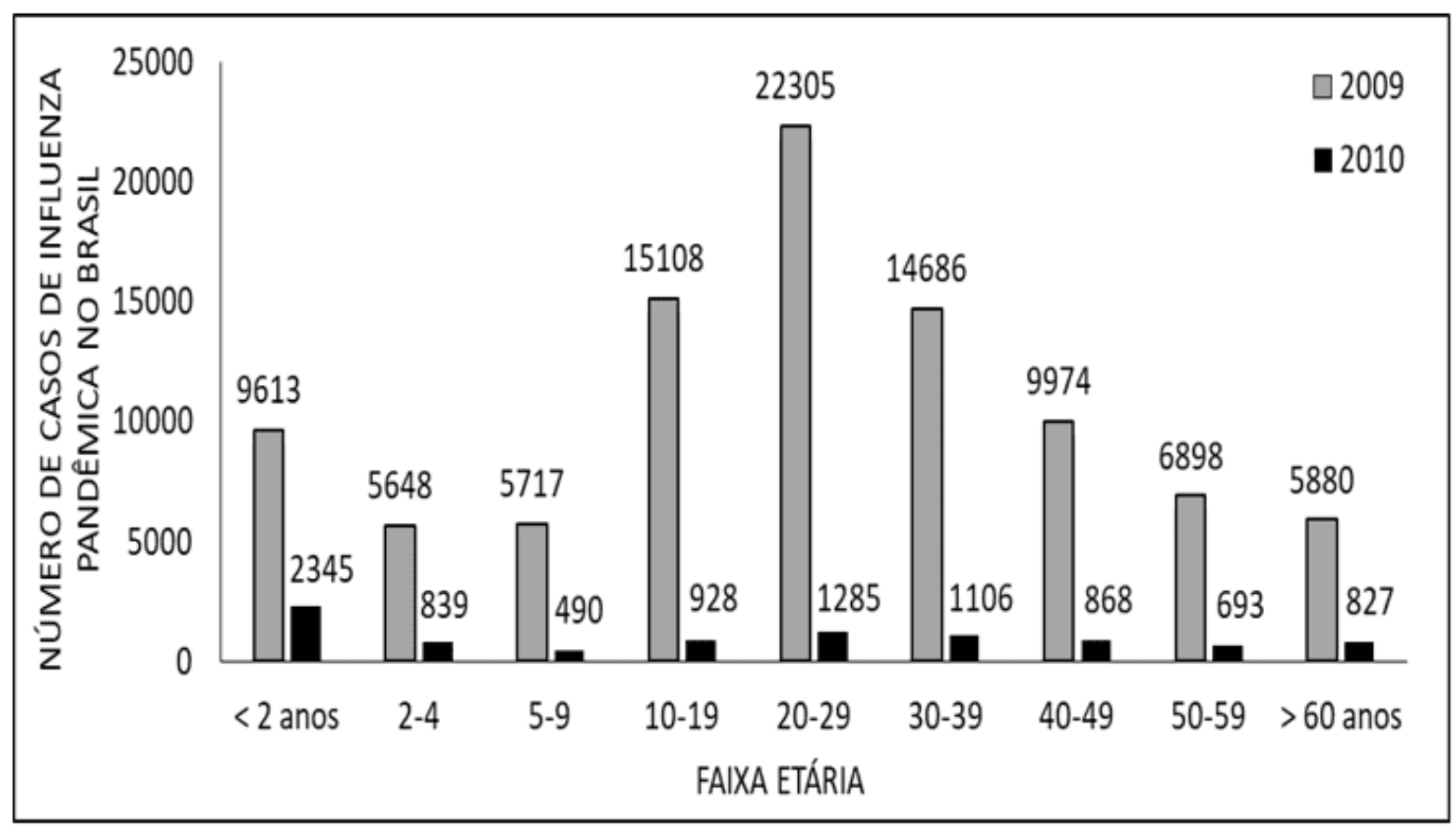

Figure 6 shows that, for both 2009 and 2010, the number of cases of pandemic influenza reached mainly the declared white population, and the declared indigenous population was less affected.

RC: 68478

Disponível em: https://www.nucleodoconhecimento.com.br/health/pandemic- 
Figure 6 Shows the number of cases of pandemic influenza in Brazil in 2009 and 2010 by race.

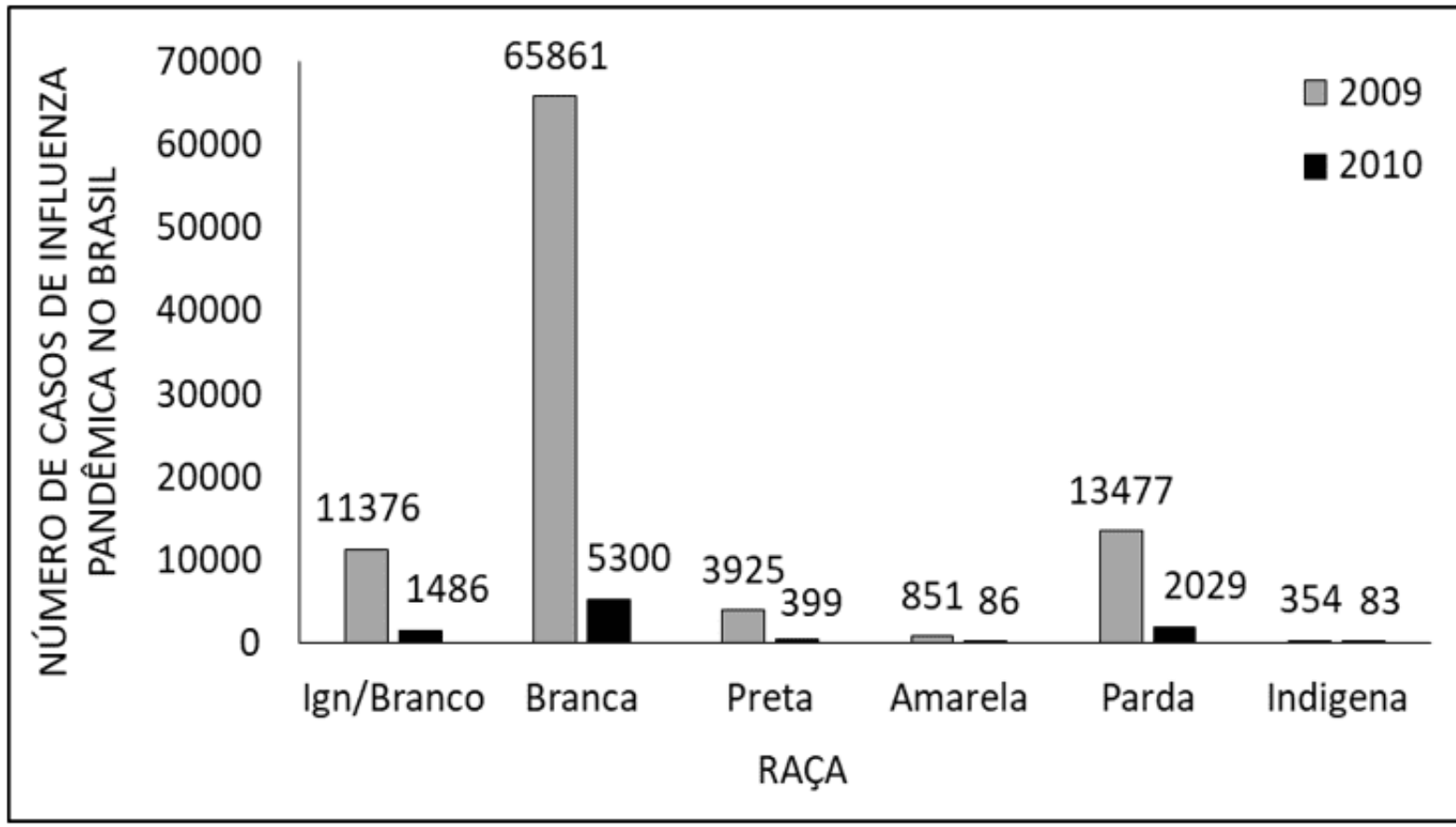

Figure 7 shows that, in 2009, the majority of the number of cases of pandemic influenza were confirmed. In 2010, most cases were dropped. Comparing the results for the two periods, it was verified that in 2009 the number of confirmed cases was about fifty times higher than in 2010.

RC: 68478

Disponível em: https://www.nucleodoconhecimento.com.br/health/pandemic- 
Figure 7 Shows the number of cases of pandemic influenza in Brazil in 2009 and 2010 by final classification.

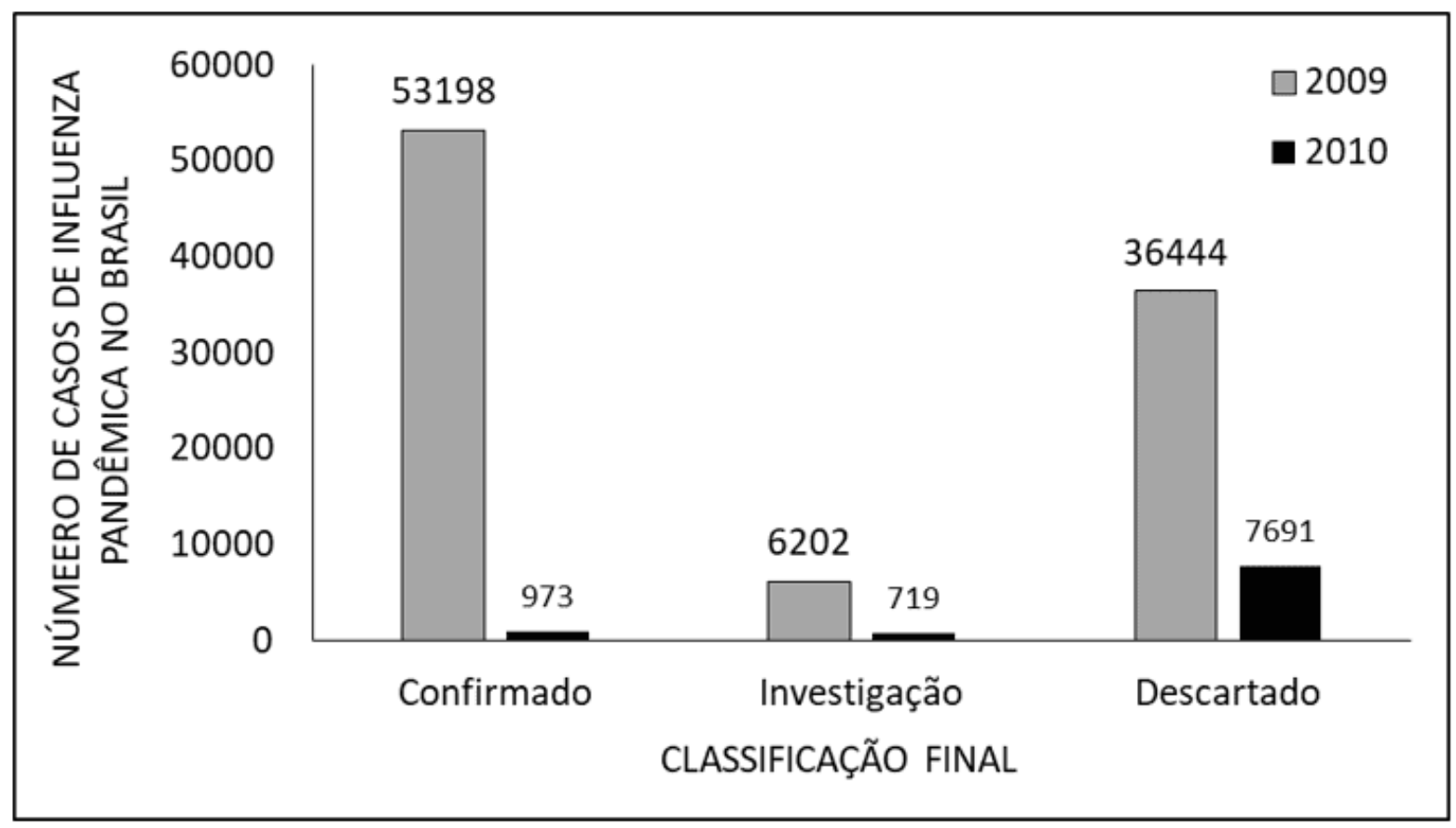

Figure 8 shows that, in 2009 and 2010, the number of individuals cured of influenza was higher than the number of deaths from pandemic influenza or other causes.

RC: 68478

Disponível em: https://www.nucleodoconhecimento.com.br/health/pandemic- 
Figure 8 Shows the number of cases of pandemic influenza in Brazil, by evolution, in the years 2009 and 2010.

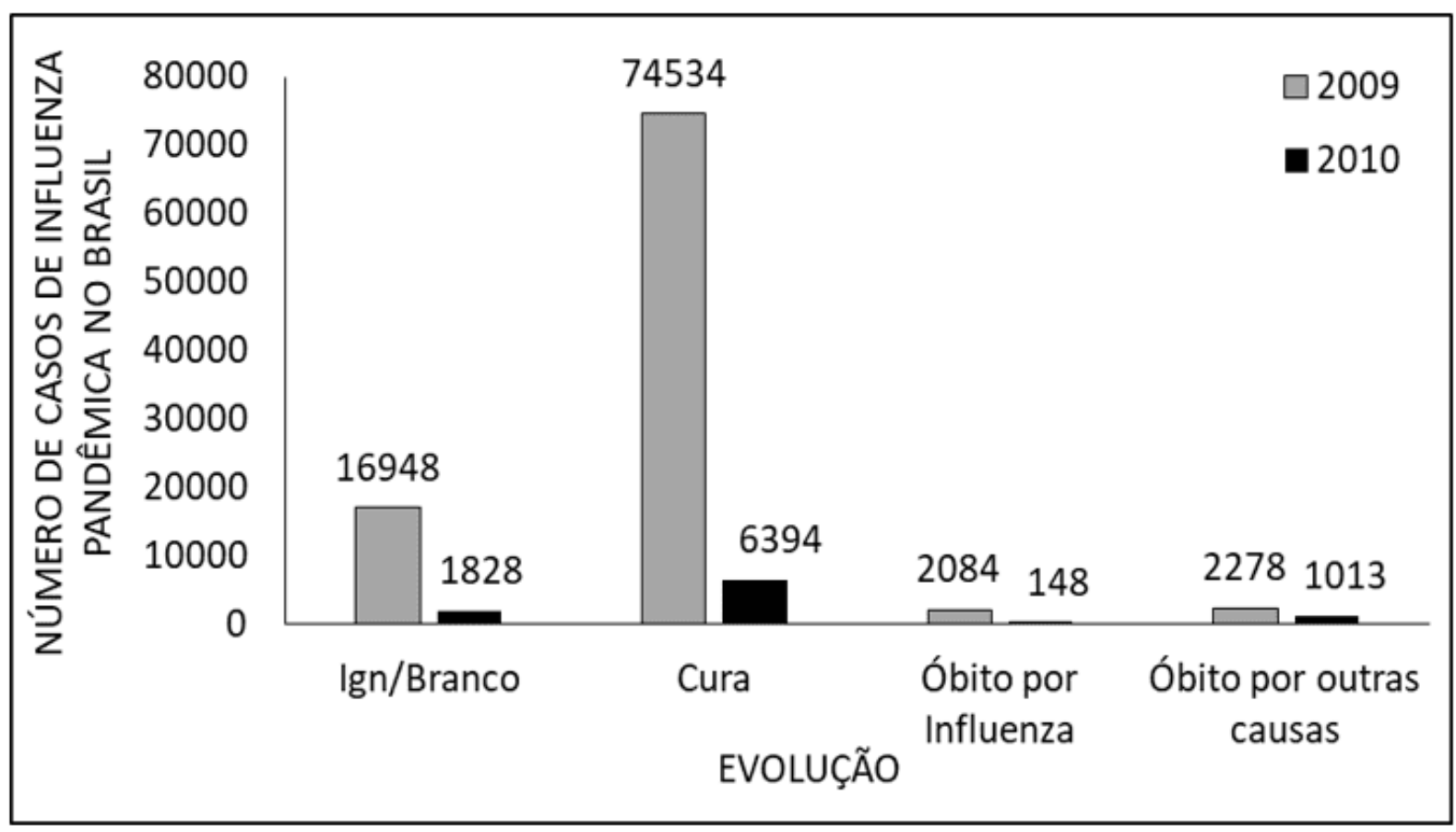

\section{DISCUSSION}

Comparing the data obtained (Figure 1) with those presented in the literature, we can see a fall in the number of cases of pandemic influenza due to immunization of the population through vaccination and early treatment with antivirals (LENZI et al., 2012). The decrease in cases may also occur due to the greater knowledge of the population about prevention and recognition of the disease (ROSSETTO AND LUNA, 2016).

The data show that, in 2009, the $2 \mathrm{nd}$, 3rd and 4th trimesters presented the highest number of influenza cases. In 2010, the 1st, 2nd and 3rd trimesters showed higher influenza numbers (figure 2). The high levels of influenza in these periods may have occurred because it is the winter season in the regions with the highest number of

RC: 68478

Disponível em: https://www.nucleodoconhecimento.com.br/health/pandemic- 
cases: the Southeast and the South of the country. In the winter period the transmission becomes greater (REIS et al., 2011).

In 2009 and 2010, the South and Southeast regions recorded the highest cases of pandemic influenza, when compared to the other regions of the country (figure 3 ). This is possible because they are regions where winter is more frequent, which favors the transmission of influenza virus (MARQUES et al., 2011). Hygiene care is reduced because it is a colder period, in which closed spaces remain and agglomerations of people are not avoided, as in warmer times (MILANESI, CAREGNATO and WACHHOLZ, 2011). Winter in these regions attracts many tourists from all over Brazil and other countries to these regions, which leads to greater transmission of the virus (GRECO et al., 2009).

The information shows that in 2009 and 2010 the female population presented the highest number of cases of pandemic influenza (figure 4). One of the possible factors that influenced this problem was the specific increase in mortality of women in the fertile age group (whether they were pregnant or not), more strongly among pregnant women (PATORELLO et al, 2012).

The data revealed that, in 2009, the highest number of cases of influenza occurred in the age group between 20 and 29 years. In 2010, the age group with the highest number of cases was that of children under two years of age (figure 5). The high number of adults with pandemic influenza in 2009 may have occurred due to the absence of an effective vaccine at the time (MACHADO, 2009). And, even if there were, adults are not qualified within the priority group for immunization (SchuelterTrevisol et al., 2012). Vaccination prioritizes children and the elderly because they have a higher risk of progressing to more severe conditions of the disease (SÁFADI, 2014). From 2010, the influenza vaccine began to be distributed throughout the public network, which reflects the fall in the number of cases from 2009 to 2010. Because it is a new vaccine, many mothers refused or stopped vaccinating their newborn children because they did not know about it or out of fear. For this reason

$\mathrm{RC}: 68478$

Disponível em: https://www.nucleodoconhecimento.com.br/health/pandemic- 
many children under 2 years of age may have contracted influenza (KFOURI and RICHTMANN, 2013).

When comparing the data obtained with that found in the literature, it is noticed that, in 2009 and 2010, the declared white population was more affected by the pandemic (Figure 6). This result can be clarified by the existing ethical and social differences. In Brazil, the majority of the population declares themselves white (IBGE, 2010). Population quotas with a larger number of people may enable greater interpersonal interaction, including those with influenza-infected individuals and travelers who have been in countries where pandemic cases have been suspected (CUGINI et al., 2010).

In 2009, most cases of influenza were confirmed and, in 2010, the largest number of cases were discarded (Figure 7). The influenza virus is extremely transmissible, a factor that can contribute to more individuals being infected by the disease and, with this, more cases are confirmed (PASTORE, PRATES and GUTIERREZ, 2012). Many individuals who presented the symptoms of influenza infection had other comorbidities with influenza-like symptoms, which may have led to most cases being discarded (ROSSETTO and LUNA, 2015).

It is noted that, in the years 2009 and 2010, there were more cases of pandemic influenza that evolved to cure (Figure 8), similar to that found in the literature. This may have occurred due to most of the infected seeking health services and starting treatment quickly, right after the first symptoms (LENZI et al., 2012). Vaccination, too, proved to be extremely necessary to avoid and reduce complications that lead to death from pandemic influenza (MARQUES et al., 2011).

\section{CONCLUSION}

In 2009, there was a high number of cases of pandemic influenza, and a large proportion of these were confirmed. However, in 2010, there was a numerical

$\mathrm{RC}: 68478$

Disponível em: https://www.nucleodoconhecimento.com.br/health/pandemic- 
reduction in cases, probably due to the expansion of population knowledge about the prevention and knowledge of the disease and its organic implications.

The influenza virus has as characteristic its extreme transmissibility, a factor that contributed to the high number of infected. Due to, possibly, climatic factors (in this case winter), cases of pandemic influenza increased in the $2 \mathrm{nd}$, 3rd and 4th quarters of 2009, in the South and Southeast regions.

The knowledge of pandemic influenza and its organic implications as a pathology favors the adoption of hygiene measures by the population, in order to reduce the possibility of contamination by the virus. However, in cold times, such hygiene care may decrease, increasing the transmission of the virus and, because of this, the number of cases is considerably increased.

It was observed that, in 2009 and 2010, there were more cases of pandemic influenza among females (mostly in women of childbearing age, whether pregnant or not), in Brazil, and consequently higher number of deaths. Moreover, during the 2009 pandemic, the most affected population in Brazil was mostly white, but it should be noted that most Brazilians declare themselves white.

When compared to 2009, in 2010 there were more cases in which the patient evolved positively, reaching the outcome of cure. The rapid search for medical services (as soon as symptoms begin) and the comprehensive population vaccination proved to be effective and decisive factors for this reduction in the number of deaths in the country.

\section{REFERENCES}

ANDRADE, G. N.; PIMENTA, A. M.; SILVA, D. A.; MADEIRA, A. M. F. Eventos adversos pós-vacinação contra influenza pandêmica a (H1N1) 2009 em crianças. Cadernos de Saúde Pública, v. 28, n. 9, p. 1713- 1724, 2012.

RC: 68478

Disponível em: https://www.nucleodoconhecimento.com.br/health/pandemic- 
BRASIL. Ministério da Saúde. Secretaria de Vigilância em Saúde. Situação Epidemiológica. Informe técnico de Influenza: Vigilância de Síndrome Respiratória Aguda Grave (SRAG), de Síndrome Gripal (SG) e de internações por CID J09 a J18. Ed. 1, 2012.

CARNEIRO, M.; TRENCH, F. J. P.; WAIB, L. F.; PEDRO, F. L.; MOTTA, F. Influenza H1N1 2009: revisão da primeira pandemia do século XXI. Revista da AMRIGS, v. 54, n. 2, p. 206-2013, 2010.

CUGINI, D. M.; SILVA, F. P. A.; ÉTTORI, H.; KRUMENAUER, M. Z.; MOREIRA, M. E.; PAULUCCI, R. S. Perfil epidemiológico dos casos de influenza A H1N1 em Taubaté - SP. BEPA. Boletim Epidemiológico Paulista, v. 7, n. 81, p. 17-25, 2010.

GRECO, D. B.; TUPINAMBÁS, U.; FONSECA, M. Influenza A (H1N1): histórico, estado atual no Brasil e no mundo, perspectivas. Revista Médica de Minas Gerais, v. 19, n. 2, p. 132-139, 2009.

IBGE, Instituto Brasileiro de Geografia e Estatística. 2010. Disponível em: < https://ww2.ibge.gov.br/home/estatistica/populacao/censo2010/defaut_resultados_a mostra.shtm?>. Acesso em: 28 de setembro de 2017.

KFOURI, R. A; RICHTMANN, R. Vacinação contra o vírus influenza em gestantes: cobertura da vacinação e fatores associados. Einstein (São Paulo), v. 11, n. 1, 2013.

LENZI, L.; MELLO, A. M.; SILVA, L. R.; GROCHOCKI, M. H. C.; PONTAROLO, R. Influenza pandêmica a (H1N1) 2009: fatores de risco para o internamento. Jornal Brasileiro de Pneumologia, v. 38, n. 1, p. 57-65, 2012.

LENZI, L.; MELLO, A. M.; SILVA, L. R.; GROCHOCKI, M. H. C.; PONTAROLO, R. Manifestações clínicas, desfechos e fatores prognósticos da influenza pandêmica $A$

$\mathrm{RC}: 68478$

Disponível em: https://www.nucleodoconhecimento.com.br/health/pandemic- 
(H1N1) de 2009 em crianças. Revista Paulista de Pediatria, v. 30, n. 3, p. 346-352, 2012.

MACHADO, A. A. Infecção pelo vírus Influenza A (H1N1) de origem suína: como reconhecer, diagnosticar e prevenir. Jornal Brasileiro de Pneumologia, v. 35, n. 5, p. 464-469, 2009.

MARQUES, D.; FIGUEIRA, G. C. N.; MORENO, E. S.; ALMEIDA, C. L.; CORDERO, R.; CAMPOS, K.; SACCHI, C. T.; TIMENETSKY, M. C. S. T.; CARVALHANAS, T. R. M. P.; KITAGAWA, B. Y. Investigação de óbito relacionado à influenza pandêmica H1N1 2009 no município de Osasco, SP, junho e julho de 2009. BEPA. Boletim Epidemiológico Paulista, v. 8, n. 85, p. 4-14, 2011.

MARQUES, F. R. B.; FURLAN, M. C. R.; OKUBO, P.; MARCON, S. S. Relação entre morbidade hospitalar e cobertura vacinal contra Influenza A. Acta Paulista de Enfermagem, 2011.

MELO, Carolina Simas. et al. Caracterização epidemiológica dos óbitos no Brasil por macrorregião de 2016 a 2018. Revista Científica Multidisciplinar Núcleo do Conhecimento. Ano 04, Ed. 12, Vol. 01, pp. 05-17, 2019. Link de acesso: https://www.nucleodoconhecimento.com.br/saude/obitos-no-brasil

MILANESI, R.; CAREGNATO, R. C. A.; WACHHOLZ, N. I. R. Pandemia de Influenza A (H1N1): mudança nos hábitos de saúde da população, Cachoeira do Sul, Rio Grande do Sul, Brasil, 2010. Cderno de Saúde Pública, v. 27, n. 4, p. 723-732, 2011.

PASTORE, A. P. W.; PRATES, C.; GUTIERREZ, L. L. P. Implicações da influenza A/H1N1 no período gestacional. Scientia Médica, v. 22, n. 1, p. 53-58, 2012.

PASTORELlO, C. M.; ROCHEMBACH, A.; DORING, M.; MORETTO, E. F. S.;PETUCO, V. M.; DALMOLIN, M.; SEIDLER, J.; SANTETTI, G. Impacto da

RC: 68478

Disponível em: https://www.nucleodoconhecimento.com.br/health/pandemic- 
influenza (H1N1) 2009 e de doenças respiratórias na mortalidade de mulheres em idade fértil no estado do Rio Grande do Sul, Brasil, 2008-2009. Epidemiol. Serv. Saúde, v. 21, n. 2, p. 205-212, 2012.

REIS, P. O.; ISER, B. P. M.; SOUZA, L. R. O.; YOKOTA, R. T. C.; ALMEIDA, W. A. F.; BERNAL, R. T. I.; MALTA, D. C.; OLIVEIRA, W. K.; PENNA, G. O. Monitoramento da síndrome gripal em adultos nas capitais do Brasil e no Distrito Federal por meio de inquérito telefônico. Revista Brasil epidemiológico, v. 14, n. 1, 2011.

ROSSETTO, E. V.; LUNA, E. J. A. Aspectos clínicos dos casos de influenza $\mathrm{A}(\mathrm{H} 1 \mathrm{~N} 1)$ pdm09 notificados durante a pandemia no Brasil, 2009-2010. Einstein (São Paulo), v. 13, n. 2, p. 177-182, 2015.

ROSSETTO, E. V.; LUNA, E. J. A. Relacionamento entre bases de dados para vigilância da pandemia de influenza A (H1N1) PDM09, Brasil, 2009-2010. Cadernos de Saúde Pública, v. 32, n. 7, 2016.

SÁFADI, M. A. P. Sociedade Brasileira de Imunização 2014/201 Gripe 2015. Revista imunizações, v. 7, n. 3, 2014.

SAKAI, M.; GUEDES, D.; CORRÊA, E. J.; ROCHA, R. L.; REGGIANI, M.; LANÇA, S. B.; PEDROSO, E. R. P. Infecção pelo vírus Influenza pandêmico (H1N1) 2009. Revista Médica de Minas Gerais, v. 20, n. 4, p. 578- 593,2010.

SCHUELTER-TREVISOL, F.; DUTRA, M. C.; ULIANO, E. J. M.; ZANDOMÊNICO, J.; TREVISOL, D. J. Perfil epidemiológico dos casos de gripe A na região sul de Santa Catarina, Brasil, na epidemia de 2009. Revista Panam Salud Pública, v. 32, n. 1, 2012

Submitted: November, 2020.

Approved: November, 2020.

$\mathrm{RC}: 68478$

Disponível em: https://www.nucleodoconhecimento.com.br/health/pandemic- 